\title{
THE DYNAMIC OF BILATERAL RELATIONSHIP BETWEEN THE REPUBLIC OF INDONESIA- KINGDOM OF SAUDI ARABIA IN THE FIELD OF POLITIC
}

\author{
Muhammad Ibrahim Hamdani ${ }^{1}$, Muhammad Luthfi' \\ \{1muhammad.ibrahim62@ui.ac.id, ${ }^{1}$ m.luthfiz009@gmail.com\} \\ ${ }^{1,2}$ School of Strategic and Global Studies, Universitas Indonesia, Indonesia
}

\begin{abstract}
The billateral relationship between The Republic of Indonesia (RI) and The Kingdom of Saudi Arabia (KSA) face some serious challenges in political field. For the example, many Indonesian Migrant Workers (IMW) in Saudi Arabia accept some serious problems. So do with the high gap between the total export value of Indonesia to Saudi Arabia and the vice versa. This condition causes Indonesia still not considered important by the KSA government. This matter is visible from span of 48 years between the official visit of King Faisal bin Abdul Aziz al Saud to Indonesia on 10-13 June 1970 until the official visit of King Salman bin Abdul Aziz al Saud to Indonesia on 112 March 2017. Even the KSA government only put two attaches at the KSA Embassy in Jakarta, The Religious Affairs Attache and The Military Affairs Attache. Otherwise, the RI government put six attaches at the RI Embassy in Riyadh: Political Attache, Defense Attache, Manpower Attache, Trade Attache, Education Attache, and Police Attache. There is also Legal Attache at Consulate General of RI in Jeddah. This research aims to discuss the dynamics of billateral relations between Indonesia and Saudi Arabia in political fields. Especially since the post-official visit of King Faisal untill King Salman's offivial visit to Indonesia. Then, the analysis knife used in this research is the concept of interdependence and the strong state theory. The results of this study are also useful to evaluate the extent to which primordialism factors between Indonesia and Saudi Arabia are important in strengthenning billateral relation between the two countries. Particularly, the identity of Indonesia as the largest Moslem country in the world, and the largest number of Hajj Pilgrims in the world.
\end{abstract}

Keywords: Indonesia, Saudi Arabia, Bilateral Relation, Muslim, Hajj, Attache

\section{PRELIMINARY}

This research is inspired by the imbalance in the number of diplomatic attache in the bilateral relations between RI and KSA. The government of KSA put two diplomatic attaches on the Embassy of KSA in Jakarta, Indonesia, namely Attache of Military Affairs and Attache of Religious Affairs. (Boxalamat.com, 2016). On the contrary, the government of RI put seven diplomatic attaches on the Embassay of RI in Riyadh, Saudi Arabia. Those seven attaches are 
Attache of Education and Culture (atdikriyadh.org), Attache of Law (Putra, Kompas.com, 2017), Attache of Politic, Attache of Defense, Attache of Police, Attache of Manpower, and Attache of Trade. (Kemlu.go.id). The government of RI also put the Attache of Transportation on the General Consulate of RI in Jeddah, Saudi Arabia. (Dephub.go.id).

The existence of diplomatic attaches reflect the priority interest of a country's foreign policy to another country. So that Islam and military are the main priorities of Saudi Arabia's foreign policy in Indonesia. While the main priority of Indonesia's foreign policy in Saudi Arabia includes eight fields. Those eight fields are politic, defense, police, manpower, trade, transportation, education and culture. Thus, Indonesia's economic and foreign policy interests in Saudi Arabia are far greater than Saudi Arabia's economic and foreign policy interests in Indonesia. As a result, there are imbalances in the bilateral relations between RI and KSA.

Another obstacle factor of the relationship between RI and KSA is a span of 47 years between the honorary visit of King Faisal bin Abdul Aziz al Saud to Jakarta, on 10-13 June 1970, until the honorary visit of King Salman bin Abdul Aziz al Saud, on 1-12 March 2017, to Jakarta, Bogor, and Bali. The 47 years lag proves that the position of Indonesian geopolitic still not become the top priority in the scope of the foreign policy from the government of KSA. On the contrary, every President of RI has made a state visit to Riyadh, Jeddah, Mecca, and Madina. The aim were for state visits, Hajj Pilgrim and Umrah.

During the state visit to Indonesia, King Faisal was greeted directly by President Soeharto and some ministers of the Development Cabinet I in Kemayoran International Airport, Jakarta. King Faisal and all members of the KSA delegation attended a state dinner with President Soeharto and First Lady, Siti Hartinah Soeharto. Also attended the figures of Islamic community organizations in Indonesia. Even King Faisal visited the building of the House of Representatives (HoR) of Mutual Cooperation (Gotong Royong) of RI. There, King Faisal expressed his stance regarding bilateral relation and frienship between the two countries that have been establihed since centuries ago. (Video ANRI, 1970).

47 years after the state visit of King Faisal, King Salman visited to Jakarta, Bogor, and Bali, Indonesia, on March, 1-12, 2007. King Salman wne to Indonesia together with 25 princes, 14 royal ministers, and 87 other core groups. The total number of King Salman's core group was 112 people. King Salman spent 12 days on this state visit. The whole group of King Salman numbered 1.500 people. (Hamdani, dmi.or.id, 2017).

\section{RESEARCH METHOD}

This research uses a qualitative method with literature research technique and in-depth interviews with competent speaker who understand the bilateral relationship between RI and KSA. This research use a qualitative method to explore a number of phenomena related to the bilateral relation between RI and KSA which are often stretched and not always harmonious. This research requires data collection specifically from experts who has been interviewed indepth.

In the context of the bilateral relation between RI and KSA, There are a number of fact propositions that have the same characteristics in certain classes. For example, the comparison of the number of diplomatic attaches. These facts compare the needs, capacities and national interests of the two countries, and also become a trigger for the dynamics of bilateral relations between RI and KSA. The author will try to find a correlation from the result of the comparison of the propositions.

Another fact proposition is the number of Hajj pilgrims from Indonesia whose quota is the largest in the world. The government of KSA also earns foreign exchange profits from the 
large number of Hajj pilgrims from Indonesia who perform Hajj and Umrah in the holy cities of Mecca and Madina.

\section{THEORITICAL FRAMEWORK}

This research uses strong state theory and interdependence theory to analyze the bilateral relation between RI and KSA in the field of economy and politic. Both of these theories are used generally in the relm of international reltions and political science.

Interdependence

In Dasar Dasar Hubungan Internasional, Umar Suryadi Bakri describe the term interdependence in lexical meaning or the meaning of the word which means interdependence among the countries. Interdependence occurs because each country certainly has shortcoming amid their repective comparative advantages. Bilateral and multilateral cooperation among the countries was born because of the shortcoming and comparative advantages of each country. This coperation ultimately leads to interdependence among the countries where each country that cooperates need each other. (Bakri, 2017, p. 77).

In a situation of interdependence among the countries, the relationship among the actors is marked the emergence of cooperation and competition involving countries and transnational actors. In interdependence, there are effects of resiprocal transactions among the actors. Various policies and actions of one actor have a huge impact for the policies and actions of other actors, and vice versa. Interdependence does not only mean peace and cooperation among the actors, including state actors and transnational actors. Interdependence also means a relationship among the actors characterized by cooperation, dependence, and interaction in a number of fields. Even interdependence also includes the emergence of conflict and competition among actors. (Bakri, 2017, p. 78).

In the context of bilateral relation between RI and KSA, the theory of interdependence can be seen from the export-import balance of the two countries, especially oil and gas trade transaction. Interdependence can also be seen from the large number of IMW who work in Suadi Arabia, as well as the number of Indonesian Hajj pilgrims whose quota is the largest in the world. This means that the two countries are trying to fulfill their respective national interests through billteral cooperation. The bilateral relation between RI and KSA is also result in cooperation, dependency, interaction, conflict, and competition.

Strong State Theory

In Membangun Negara Kuat, Kontribusi Islam Terhadap Pemikiran Politik Barat, Abdul Muta'ali wrote that strong state theory is a concept of the role of the state in the midst of various kinds of problem that occur troughout the world at the beginning of the 21-st century. Fukuyama wanted to examine how the role of the state in the midst of the civil war, hunger, the spread of HIV (Human Immunodeficiency Virus)/ AIDS (Acquired Immune Deficiency Syndrome), acts of terrorism, the spread of various infectious diseases, and poverty in various countries. These various problems prove the failure of the state in overcoming the current political situation. Especially the role of the state as the highest community institution. (Muta'ali, 2013, p. 10).

In Memperkuat Negara: Tata Pemerintahan dan Tata Dunia Abad 21, Francis Fukuyama measures the strength or weakness of the state based on the scope of state activities, as well as the strength and power of the state. The scope of state activities refers to various functions and objectives carried out by the government. While the strength and power of the state refers to the ability of the state to plan and implement various state policies. Including the ability of the 
state to enact laws and implement them in a clean and tranparent manner. (Fukuyama (translation), 2005, pp. 8-9).

\section{RESEARCH PURPOSE}

This research aims to determine what factors hinder bilateral relations between RI and KSA in the field of politic. The factors are also related with military and security relation, the conflicts in Middle East Area, and the Hajj and Umrah management in Saudi Arabia.

\subsection{The Obstacle Factor of The Bilateral Relationhip Between Indonesia And Saudi Arabia}

There are some obstacles in the billateral relation between RI and KSA. One of them is a span of 47 years between the honorary visit of King Faisal, in June 11-13, 1970, untill King Salman, in March 1-12, 2017, to Indonesia. Another obstacle factor is the number of diplomatic attaches of the government of KSA in the Embassy of KSA in Jakarta, Indonesia, which is far less than the number of diplomatic attaches of the government of RI in the Embassy of RI in Riyadh, Saudi Arabia. Another obstacle is the problem in the management of the Hajj by the government of KSA. The government of RI is also establish diplomatic relations with some countries like State of Qatar and Islamic Republic of Iran. Even though both of the countries do not have diplomatic relation with the government of KSA. As a result, the relations of defense and security between Indonesia and Saudi Arabia often experience ups and downs as the conflict in the Middle East.

The author has conducted a face-to-face interview with the Head of Chancery of the Consulate General of RI in Jeddah, Rahmat Aming Lasim, on Sunday, March 4, 2018. This interview took place at Al-Muallifin Street, Al-Rehab District, Jeddah, KSA. Rahmat Aming stated that the government of KSA still not considered Indonesia as a strategic country. So far, Indonesia is only considered by the government of KSA as the exporter country of the Indonesian Migrant Workers (IMW).

"The government of KSA has not seen Indonesia as a strategic country. Maybe because Saudi Arabia is still not intact looking at Indonesia's potential. During this time, Saudi Arabia only looked at Indonesia from three things, namely the labour exporting country, the sender of the Hajj pilgrims, and the sender of Umrah pilgrims. Even ordinary people (ordinary citizens) see us (Indonesia) as poor country. There are also many Saudi Arabians who don't know Indonesia. They only know the Puncak Area, even though Indonesia is vast," said Rahmat.

In current situation, it is very logical for the government of KSA to only places two diplomatic attaches on the Embassy of KSA in Jakarta, Indonesia, namely Attache of Military Affairs and Attache of Religious Affairs. On the contrary, the government of RI place a number of diplomatic attaches on the Embassy of RI in Riyadh, Saudi Arabia. They are Attache of Education and Culture, Attache of Law, Attache of Politic, Attache of Defense, Attache of Police, Attache of Manpower, and Attache of Trade. Even the government of RI opened the Consulate General of RI in Jeddah, complete with the office of Indonesian Trade and Promotion Centre (ITPC).

Rahmat Aming also explained the positive impacts of the state visit of King Salman to Jakarta, Bogor, and Bali for 12 days, since Wednesday untill Sunday, March 1-12, 2017. For Indonesia, this visit is also became the free tourim promotion, beside the signing of six Memorandums of Understanding $(\mathrm{MoU})$, three Cooperation Programs, one Cooperation 
Agreements, and one Jont Declaration. King Salman also realized that Indonesia is a safe and comfortable place, especially when travelling in Bali. This information is immediately spread to various citizens of Saudi Arabia. Rahmat was focuses on the major changes that are happening in Ssaudi Arabia through the Vision 2030 of KSA.

The state visit of King Salman to Jakarta, Bogor, and Bali, Indonesia, was just happened 47 years after the state visit of King Faisal to Jakarta, on June 11-13, 1970. Various events occured within 47 years. Including things that are obstacles to billateral relations between the two countries in the field of politic. This condition will be discussed in the next sub-section

\subsubsection{The State Visit of King Faisal to Indonesia}

The first fisit of King Faisal to Jakarta, Indonesia, on June 10-13, 1970, had open a new chapter in the billateral relation between RI and KSA in the early era of President's Soeharto administration. As quoted from Jejak Langkah Pak Harto 28 Maret-23 Maret 1973, the arrival of the leader of KSA was greeted directly by President Soeharto and the First Lady, Siti Hartinah (Tien) Soeharto, at the Merdeka Palace, Jakarta, on Wednesday, June 10, 1970. In the presidential room, President Soeharto and Mrs. Tien Soeharto invited King Faisal and all delegation members of KSA to talk for about 30 minutes. In this meeting, Presiden Soeharto was accompanied by the Minister of Foreign Affairs of RI, Adam Malik, the State Minister of RI, Idham Chalid, and Ambassador of RI to KSA, Aminuddin Aziz. In the evening, President Soeharto held a state dinner to honor the visit of King Faisal. Both Head of State made speeches after the state dinner. In his speech, President Soeharto reiterated the position of the government of RI which was fully standing on the Arab side in the struggle against Israel. Even President Soeharto explained that Indonesia has made every effort, trough various forums, so that the United Nation (UN) Security Council resolution in 1967 can be fully implemented. The government of RI is also made a number of efforts so that the results of the Jeddah Conference initiated by King Faisal can be carried out in order to resolve the Middle East crisis. (Documentation Team of President of RI, Series 2: 2003, p. 235).

President Soeharto's statement was welcomed by King Faisal. In his speech, King Faisal stated that the firmness of Indonesia's stance, which clearly sided with the Arabs in their struggle, no one can deny it. King Faisal was determined to continue to improve and develop relations between the two countries. The reason is that the relationship that has been established is not only in recent times, but is a tradition based on trust in Allah and Rasulullah, Muhammad Sallallaahu alaihi Wassallam (SAW). As a symbol of friendship between the two countries, President Soeharto also gave a souvenir to King Faisal in the form of a keris and a tiger that had been preserved. In contrast, King Faisal gave President Soeharto an Arabic sword that was gilded in gold. (Documentation Team of President of RI, Series 2: 2003, p. 235).

On Thursday morning, June 11, 1970, President Soeharto and King Faisal resumed negotiation afor about 90 minutes in Merdeka Palace, Jakarta. Both Heads of state discuss about some problems related to the Middle East Crisis and economic cooperation between the two countries. In this meeting, President Soeharto reaffirmed the commitmend of the government of RI to continue for support ing the struggle of Arabs. Related to the economic cooperation between RI and KSA would be discuss next in the level of minister of Trade from both countries. (Documentation Team of President of RI, Series 2: 2003, p. 235-236).

The government of KSA sees that the geopolitic position of Indonesia is very strategic viewed from the international security aspect. When visited to Indonesia on June 10-13, 1970, King Faisal specifically discussed abou the Middle East crisis with President Soeharto in 
Merdeka Palace, Jakarta, for about 90 minutes. In contrast, the government of RI sees that the position of Saudi Arabia is strategic viewed from the aspect of economy. President Soeharto also offered the cooperation in economy and trade to King Faisal. In this meeting, President Soeharto proposed the economic cooperation between the two countries. The proposal was greetly welcome by King Faisal to discuss next in ministerial level.

\subsubsection{Confrontation of Indonesia-Malaysia and King Faisal's Stance}

The arrival of King Faisal to Indonesia was became the positive response of the government of KSA to the foreign policy of the government of RI which ended the confrontation to the Federation of Malaysia. On August 4, 1966, an agreement was reached between the government of RI and the government of The Federation of Malaysia to establish an diplomatic relation. This agreement was the realization or the follow up of the signing of the agrreement of the relationship normalization of the two countries which achieved in Bangkok, Muangthai (Thailand). This negotiation was held on May 29, 1966 untill June 1, 1966. This agreement was continued by the statement of the Head of The Presidium of Ampera Cabinet, Soeharto, on August 20, 1966. According to Soeharto, the government and the people of Indonesia sincerely hoped that the relationship which had just been established with the government and the people of Malaysia could be strengthened for the benefit and joint progress. (Documentation Team of President of RI, Series 1: 1991, p. 103 and 105).

One of the important role of King Faisal for ummah and the Islamic World was pioneering the Islamic World Conference or Muktamar Al-Alam Al-Islami. This conference was held by Rabithah Al-Alam Al-Islami or the League of The Islamic World which its first conference took place in the Kingdom's Palace in Al-Mu'abadaah, Riyadh. This conference was officially opened on Sunday, Dzulhijjah 17, 1384 Hijriah (1965 Masehi) by King Faisal. In this conference, also discussed the issue of conflict and the physical confrontation between Malaysia and Indonesia which was increasingly sharp and alarming for the Islamic World. Specifically, Muktamar Al-Alam Al-Islami stated its official stance for the confrontation between Indonesia and Malaysia. The conference feel very sad for the continuing conflict between fellow Muslim from the people of Indonesia and Malaysia. (Said, translate, 2014, p. 108 and 155).

According to the conference, conflict only destroyed the potential of Indonesia and Malaysia and eliminate the power of the two countries. Conflict only resulting the war which will not give the benefit, except the hostility between them. The conflict of IndonesiaMalaysia only creates many weakness in both countries. As a result, the enemy can enter easily to intervene among siblings. This certainly threatens freedom for the two Islamic countries. The conference caaling for the government of Indonesia and Federation of Malaysia to stop every hostility. In particular, the conference also sent message to Indonesia and Malaysia, and generally to the Islamic Countries, to exert all the abilities to stop this conflict with the peacefull ways. (Said, translate, 2014, p. 155).

As the host and organizer of Muktamar Al-Alam Al-Islami, the response of this conference to the conflict of Indonesia-Malaysia is of course became the ofiical stance of the government of KSA under the administration of King Faisal. With another word, the government of KSA chooses not to take side to one of the both countries who conflicting each other. This impartiality was taken in order to maintain good relations among the government of KSA and the two countries. Even the Khadimul Haramain or the Servant of the Two Holy Land actually gave a stromg warning to Indonesia and Malaysia about the magnitude of the potential for foreign intervention which would only weaken the strength of the two countries and Muslims 
around the world. It is feared that foreign parties intervention can threaten the sovereignty, independence and security of the two countries.

The firm message of Muktamar Al-Alam Al Islami to Indonesia and Malaysia to immediately stop the conflict, finally responded positively by the two countries. In Jejak Langkah Pak Harto, 1 Oktober 1965-27 Maret 1968, the Deputy Prime Minister/ The Minister of Foreign Affairs of RI, Adam Malik, stated that Indonesia was willing to peacefully settle a dispute with Malaysia. This statement was said on May 2, 1966, in the official visit of Adam Malik to Bangkok, Thailand. Adam Malik's statement accompanied by the statement of Deputy Prime Minister/ Army Commander of RI, Soeharto. In an interview with a Japan newspaper, Asahi Shimbun, on May 4, 1966, Soeharto stated that Indonesia would not close the door to resolve the conflict peacefully in accordance to Manila Agreement. But Soeharto acknowledged that the relationship between Malaysia and Indonesia still happened in an confrontative situation. Confrontation is the way of the government of RI to support the struggle of the people of Sabah and Serawak. Confrontation was also became the way to at least support the implementation of the right to self-determination democratically, based on the UN decision on decolonization and Manila Agreement. (Documentation Team of President of RI, Series 1, 1991, p. 73-75).

The completion of the confrontation of Indonesia-Malaysia continous in negotiation between the two countries in Bangkok, Thailand. In June 13, 1966, Deputy Prime Minister for Defense and Security/ Minister of Army Commander of RI, Soeharto, explained that the results of the negotiation between the delegates of Indonesia and Malaysia continued to be reviewed together with Permanent Secretary of the Ministry of Foreign Affairs of Malaysia, Ghazali bin Shafie. This negotiation provide the clue about the desire of Soeharto to end the confrontation of both countries. That confrontation issued by the regime of Old Order since the proclaimed of Federation of Malaysia in September, 1963. In June 15, 1966, Soeharto met and talked with Deputy Prime Minister/ Minister of Foreign Affairs of RI, Adam Malik, and Deputy Prime Minister of RI, Sri Sutan Hamengkubuwono IX. The meeting discuss about the result of the negotiation between Indonesia and Malaysia in Bangkok. According to Soeharto, principally, there were not different interpretations among the three Deputy Prime Ministers about the results of negotiation in Bangkok. (Documentation Team of President of RI, Series 1, 1991, p. 84-85).

\subsubsection{Ups and Downs of Defense and Security Cooperation of RI-KSA}

During the reign of the New Order, it was noted that President Soeharto received a visit of Deputy II Prime Minister/ Minister of Defence/ Minister Air Transportation of KSA, Prince Sultan bin Abdul Aziz Al Saud, and all the delegates on Monday, December 12, 1983, at 11:15 WIB, in Bina Graha, Presidential Palace, Jakarta. In this delegation, also attended Prince Khalid bin Abdullah and Ambassador of KSA to RI, Mohammed Said Basrawi. The delegates of KSA was accompanied by the Minister of Defence and Security of RI, Poniman. According to Poniman, this meeting discuss the issues of the increased relations and cooperation between Indonesia and Saudi Arabia. However this meeting din not disccus about the issues of military cooperation. President Soeharto and Prince Sultan more emphasis on various issues related to interest of the two countries. (Documentation Team of President of RI, Series 5, 2003, p. 87-88).

Thus, the problem of defense and security became a major concern for the government of KSA in establishing the billateral relation with the government of RI, especially the security issues in the Middle East Area. This visit was carried out in line with the escalation of the 
conflict between Saudi Arabia and Iraq before the outbreak of the Gulf War I on August 2, 1990. At that time, there was also a war between Iraq and Iran which began to erupt on November 22, 1980 and ended on August 20, 1988. As a result, the government of KSA felt threatened so that the security issues become the main concern of the government of KSA in its foreign policy. Especially for Indonesia as the largest Muslim population in the world.

When talked to Prince Sultan, President Soeharto also did not discuss about the military cooperation between Indonesia and Saudi Arabia. It means that the government of RI avoid the military cooperation with KSA because Indonesia adhered to a free and active foreign policy and do not want to side with one or more countries in conflict in the Middle East area.

On Sunday, August 9, 1990, at 11:00 WIB, President Soeharto and Minister of Foreign Affairs of RI, Ali Alatas, received the special envoy of the government of KSA, Abdul Aziz al-Thenayun, at the President's residence, Cendana Street, Jakarta. That Special Envoy came came to Indonesia to deliver a personal message of King Fahd bin Abdul Aziz al Saud about the increasingly warm conflict situation in Middle East area after the invasion of Iraq against Quwait. The problem is the government of Iraq is threatening to attack Saudi Arabia. To that Special Envoy, President Soeharto affirmed the Indonesia's stance about the Gulf War. The government of RI would not sent troops to Saudi Arabia to join multinational forces whose aim to prevent the government of Iraq's invasion to Saudi Arabia. ((Documentation Team of President of RI, Series 6, 2004, p. 334).

However, the government of RI has argued that the invasion of Iraq to Kuwait is completely unjustified. President Soeharto explained to Abdul Aziz al-Thenayun that according to Indonesian constitution, President had not authority to sent soldiers abroad in wars. President also hoped that the government of Iraq did not attack its neighbour countries so that the conflict situation in Middle East would not getting more acute and the armed conflict between Iraq and Kuwait can be resolved peacefully. (Documentation Team of President of RI, Series 6, 2003, p. 334).

1990-1991 was a very important year for the billateral relation between Indonesia and Saudi Arabia. In particular, about the position of both countries in facing the conflict in Middle East. This condition was very related to the Gulf War I between Iraq versus Kuwait who assisted by the United Stated of America (USA)-led coalition forces. The problem is the government of KSA became a member of the USA-led coalition force so that Saudi Arabia was threatened by Iraq. Iraq had nuclear weapon under the administration of President Saddam Hussein. These critical years were addressed by the government of RI by reaffirmed the stance to not send military aid to KSA or to countries involved in the Middle East conflict.

The government of RI was also very strict in its stance regarding the Iraqi attack on Kuwait. The attack cannot be justified for any reason. Moreover, Kuwait is a sovereign country whose independence is recognized by Indonesia and the UN members. de facto and de jure. This stance reflects Indonesia's foreign policy which is free and active. It cannot be dictated by foreign countries to send Indonesian Armed Forces (ABRI) troops abroad.

The defense cooperation between RI and KSA entered a new phase in 2014. This was marked by the visit of Deputy Minister of Defense of KSA, Prince Salman bin Sultan bin Abdul Aziz al Saud, to Indonesia in January 2014. Prince Salman has signed a defense agreement with the government of Indonesia. This agreement is the first time to sign by the government of RI with countries in the Middle East. Especially regarding the two countries attention to terrorism issues. (Machmudi, 2016, pp. 286-287).

The defence cooperation between RI and KSA has increased in the era of the administration of Presiden Soesilo Bambang Yudhoyono. This was reflected in the visit of the Deputy Minister of Defense of KSA, Prince Salman, to Indonesia in 2014. For the first time, 
the government of Indonesia and KSA signed a Defense Agreement between the two countries with a focus on terrorism issues. This event is very important because it is the initial stage of defense cooperation between the two countries in combating terrorism. The culmination point occurred during the visit of King Salman to Bogor, Jakarta and Bali for 12 days, March 1-12, 2017.

The Chief of Police of KSA, Othman bin Nasser al Mehrej, also visited to Indonesia in April 18, 2017, to met with the Chief of Police of RI, Muhammad Tito Karnavian. The visit of Othman aims to follow up the MoU between the Police of RI and the Police of KSA. Previously, the Chief of Police of RI and The Chief of Police of KSA and KAS signed a Cooperation Agreement at the Bogor Palace, when King Salman visited Indonesia in 2017.

During this visit, the Police of RI and the Police of KSA jointly agreed on a number of things such as eradicating transnational crime. These crimes included terrorism, human trafficking, and narcotics abuse and illegal drugs. Technically, the two countries also agreed to exchange information about the crime. Other cooperation is in the field of human resource development. For example, many Saudi Arabian police who studied at the Leadership School of the Police of RI. (Movanita, Kompas.com, April 2017).

The Chief of Police of RI, Muhammad Tito Karnavian, and The Commander of Indonesian National Army (INA), Gatot Nurmantyo, were also visited Saudi Arabia. This visit aims to fulfill the invitation of the pilgrimage from King Salman. Both arrived in Mecca on Monday, August 28, 2017. In this visit, The Chief of Police of RI and The Commander of INA were greeted by the Chief of Police of KSA, Said bin Abdullah al Qahtani. Tito Karnavian appreciated the hajj safeguards in Saudi Arabia supported by 70,000 police personnel, 5,000 special closed circuit television (CCTV) in the Masjidil Haram and 550 CCTVs in Arafah (Amelia R, detik.com: 2017). Other sources said that Said bin Abdullah AlQahtani also served as Operations Assistant to the Minister of Interior of KSA concurrently Acting Director General of Public Security of KSA or the Chief of Police of KSA. The Chief of Police of RI also took the time to visit the KSA Police Control Center. (Movanita, kompas.com: August 2017).

The signing of the security cooperation between RI and KSA proved that Indonesia is a strong country. In the eyes of the government of KSA, Indonesia has a very strategic geopolitical position in the field of defense and security. Moreover, Indonesia is predicated as the fourth largest population in the world after China, the United States, and Russia. Indonesia is also predicated as the largest Muslim population in the world, around 207,176,162 people, as well as the largest archipelagic country in the world with 17,504 islands. With these various potentials, the step of the Police of KSA to establish strategic alliances with the Police of RI is appropriate and rational. Especially the cooperation between the Police of RI and Police of KSA to fight the transnational crimes such as terrorism, drug abuse and human trafficking. This condition became the logic reason for the government of KSA to place the Attache of Military Affairs at the Embassy of KSA in Jakarta, Indonesia.

Intensifnya kerja sama antara RI dan KAS dalam bidang pertahanan dan keamanan merupakan dampak langsung dari kunjungan Raja Salman ke Indonesia pada 1-12 Maret 2017. Momentum bersejarah ini ditandai oleh penandatanganan Perjanjian Kerja Sama antara Kapolri, Muhammad Tito Karnavian, dengan Mendagri KAS, Pangeran Abdul Aziz bin Saud bin Nayef bin Abdul Aziz Al Saud, pada Rabu, 1 Maret 2017 lalu di Istana Bogor. Prosesi penandatanganan ini disaksikan langsung oleh Presiden Joko Widodo dan Raja Salman. Selain itu, ditandatangani pula lima buah Nota Kesepahaman, tiga Program Kerja Sama, satu Deklarasi Bersama, dan satu Komitmen oleh Pemerintah RI dan KAS (Damarjati, Detik.com, 2017). 
Disasters in Hajj Management in Saudi Arabia

One of the major disasters that occurred during the Hajj season was a disaster in the alMu'aisim tunnel, Mina, Mecca City, Saudi Arabia, on July 2, 1990. As a result of this disaster, at least 1,426 Hajj pilgrims died from various countries, including 631 victims of Hajj pilgrims who died from Indonesia. The large number of victims died from Indonesia is in accordance with the predicate of Indonesia as the country sending the largest Hajj pilgrims in the world each year. That was why King Fahd sent his special envoy to met President Soeharto in Jakarta (Kristanti, Liputan6.com, 2015).

In Jejak Langkah Pak Harto 21 Maret 1988 - 11 Maret 1993, King Fahd sent a Special Envoy to delivered a message about the disaster in Al-Mu'aishim tunnel in Mina to President Soeharto. That special envoy is Minister of Industry and Electricity of KSA, Abdul Aziz alZamil. Then president Soeharto received the special envoy in Merdeka Palace, Jakarta, on Tuesday, July 17, 1990, only 15 days after theat disaster. In this meeting, President Soeharto was accompanied by the Minister of Religion of RI, Munawir Sjadzali. That special envoy delivered a letter and deep condolence from King Fahd for the disaster which caused the death of thousands of the Hajj, including from Indonesia. (Documentation Team of President of RI, Series 6, 2003, p. 321).

According to Abdul Aziz al-Jamil, the incident in the al-Mu'aishim tunnel was not caused by an explosion, a demonstration, a blackout, or the death of a blower. Responding to this, President Soeharto spontaneously showed his dissatisfaction with the explanation of King Fahd's Special Envoy. President Soeharto stated that he believed the Government of KSA had done much to improve services to Hajj pilgrims. But the service needs to be continuously improved along with the increasing number of Hajj pilgrims each year. According to President Soeharto, the improving services to Hajj pilgrims can only be done if all parties know the causes of the disaster. This is what the Indonesian government wanted to know from the government of KSA so that similar events would not happend again. Related to this, President Soeharto proposed that the government of KSA should build another tunnel in Mina. (The Republic of Indonesia Documentation Team, Series 6, 2003, p. 321).

King Fahd's special envoy returned to Indonesia for the second time on Saturday, March 2, 1991, at 09.00 WIB. The envoy was named Sheikh Mohammad Ibrahim Masoud. The special envoy was accepted by President Soeharto at his personal residence, Jalan Cendana, Jakarta. The Special Envoy then delivered a guarantee from King Fahd on the security of Indonesian Hajj pilgrims in the holy land of Mecca al-Mukarramah. According to Ibrahim Masoud, the government of KSA has taken various steps to provide the best services for Hajj pilgrims. Responding to this, President Soeharto welcomed Saudi Arabia's steps in serving the Hajj as well as possible. Then the President expressed his regret over the occurrence of war in the Gulf region. The Head of State of RI also put forward the government of RI's active diplomacy steps to prevent the occurrence of the Gulf War. (Presidential Documentation Team of the Republic of Indonesia, Series 6, 2003, p. 407).

The presence of two special envoys of king Fahd to met directly with president Soeharto at Merdeka Palace in 1990, and at Cendana Street in 1991 proved that there is a very strong bond between the two countries as two major Muslim-majority countries. Related to the disaster in the al-Mu'aishim tunnel, Mina, the government of KSA felt that it was fully responsible for the disaster. Even through a special envoy, King Fahd expressed deep condolences to President Soeharto for the death of 631 Indonesian Hajj pilgrims in the accident. Another important issue is that the government of KSA needs to clarify that the main cause of the disaster in the al-Mu'aishim tunnel is the jostling of the congregation, not because of an explosion, a demonstration, a blackout, or the death of a blower. 
Regarding the stance of President Soeharto, who expressed his dissatisfaction with the Minister of Industry and Electricity of KSA, Abdul Aziz al-Zamil, this meant that the Head of State of RI wanted a detailed and complete explanation about what causes of the disaster in the al-Mu'aishim tunnel. Moreover, the clarification from the Special Envoy of King Fahd only negated the alleged cause of the disaster, not explained in detail the causes of the disaster. This response meant the disappointment of the government of RI over the performance of the government of KSA's service to Hajj pilgrims who were less than optimal in responding to accidents during the Hajj season.

President Soeharto wanted to show that Indonesia was a strong country that could not be underestimated by any country, including the government of KSA. President Soeharto also wanted to provide a real solution and hoped that the similar events would not happen again in the future. This could be seen from President Soeharto's strong warning to the government of KSA to immediately investigate and find out the causes of the disaster. Even President Soeharto proposed that King Fahd should build another tunnel in Mina to facilitate the flow in and the flow out of Mina to the Masjidil Haram and the opposite direction.

It was noted that there are a number of calamities due to human error factors occurred during the Hajj season in the city of Mecca al-Mukarramah. The most recent event was the collapse of a heavy project tool (crane) at the Masjidil Haram, Mecca, on Friday, September 11, 2015, around 17:30 local time. That crane fall down together with the emergence of strong winds and very heavy rain. The rain entered the mosque floor, along with the preparation for Maghrib prayer. As a result of this disaster, as many as 87 Hajj pilgrims from various countries have died and 184 other Hajj pilgrims suffered injuries. Including two pilgrims from Indonesia who died from the embarkation of North Sumatra and West Java (Liauw, Kompas.com, 2015).

While data from the Civil Defense Authority of KSA noted that the number of Hajj pilgrims who died as a result of the collapse of the crane reached 107 people and wounded up to 238 people. This information was conveyed by the General Director of the Civil Defense Authority of KSA, Suleiman al-Amr, on Friday, September 11, 2015. (Kompas.com: 2015).

According to the Head of Regional Work Mecca. Hajj Committee (PPIH), Arsyad Hidayat, until 11:00 AM in Mecca, on Tuesday, September 15, 2015, there were 11 Indonesian Hajj pilgrims who died due to the collapse of the cranes in Masjidil Haram from a total of 107 Hajj pilgrims who died from various countries. In addition, 40 Indonesian Hajj pilgrims were injured, including minor and severe injuries, out of a total of 283 Hajj pilgrims who were injured from various countries (Hamdani, Dmi.or.id, 2015).

Responding to the crash of the crane, President Joko Widodo spontaneously conveyed deep condolences to all victims. Moreover during the incident, President Joko Widodo had just arrived in Jeddah to make a state visit. He was at the King Faisal Palace, Jeddah, on Friday, September 11, 2015. The crane used for the construction and expansion of the Masjidil Haram was broken and collapsed due to a storm. As a result, the crane befalls Hajj who are performing thawaf, including Hajj from Indonesia. President Joko Widodo then ordered the Amirul Hajj of RI, Lukman Hakim Syaifuddin, who is also the Minister of Religion of RI, to immediately monitor the developments and provide optimum assistance to all victims of the collapse of cranes in Masjidil Haram (Nursalikah, Republika.co.id, 2015).

A similar statement was expressed by the Indonesian Vice President, Muhammad Jusuf Kalla, who conveyed deep condolences for all victims of the crash of the crane at the Masjidil Haram. According to Jusuf Kalla, this disaster coincided with the sandstorm that struck the city of Mecca. The Vice President also prayed that all of God's guests (Hajj pilgrims) who died as a result of the fall of the crane became syahid. All the calamities that befall Muslims 
are a test and always have wisdom behind it. Calamity implies a warning that Muslims can come back to life in an atmosphere of peace as fellow brothers (ukhuwwah Islamiyah). This information was delivered by the Spokesperson of the Vice President of RI, Hussein Abdullah. (Hamdani, Dmi.or.id, 2015).

Less than two weeks after the crash of the crane at the Masjidil Haram, Mecca, a much greater disaster occurred again in Mina, Mecca, on September 24, 2015. The disaster occurred when the Hajj pilgrims wanted to throw jumrah in Mina, Mecca, due to jostling and being trampled on road 204 which intersects with road 223. After this incident, at least 310 Hajj pilgrims from various countries died and 450 other Hajj pilgrims were injured. (Panji, Cnnindonesia.com, 2015). According to the Minister of Religious Affairs of RI, Lukman Hakim Saifuddin, who is also Amirul Hajj of RI, there are at least 129 Indonesian Hajj pilgrims who have been identified died as a result of the disaster in Mina, Mecca. The identification process for the dead bodies of Indonesian Hajj pilgrims was carried out by the Disaster Victim Identification (DVI) Team of the Police of RI. The team consists of 10 forensics experts from the Police of RI led by Muhammad Mas'udi (Armenia, Cnnindonesia.com, 2015).

Lukman Hakim Saifuddin also stated that the government of RI would explore and seek information about the cause of the Askar or the Hajj pilgrimage security officers of KSA deflecting Indonesian Hajj pilgrims to the left or to the road 223. Supposedly, Indonesian Hajj pilgrims continue to walk straight on King Fahd's road. As a result of the deflection of the lane, Hajj pilgrims must cross line 204 to arrived at Jamarat, the location for throwing the Jumrah. Line 204 is the location of the Mina disaster due to the large number of Hajj pilgrims jostling so much that they died because they were pinched, trampled, or out of breath. According to Saudi Arabia authorities, there were at least 770 Hajj pilgrims who died and 850 other worshipers were injured. (Bbc.com, 2015).

Responding to the disaster at Mina which caused at least 700 died, President Joko Widodo expressed deep condolences to the victims. According to the President, there must be improvements in the management of the Hajj so that events in Mina will not be repeated in the future. A statement of deep condolence over the Mina tragedy was also said by the Vice President Jusuf Kalla. According to the Vice President, the emergence of a large number of casualties in the Mina incident was caused by panic factors that caused Hajj pilgrims to jostle each other. Vice President Kalla also asked all groups of Hajj pilgrims from Indonesia to discipline and follow the entire process of the Hajj by obeying their respective mentors. The Hajj Hajj pilgrims must also maintain health given the hot weather that is quite draining and requires physical endurance. (Jordan, Detik.com, 2015).

The government of RI has been firm and urged the government of KSA to immediately improve the management of the Hajj, especially in Mina. The hope is that the same accident will not happen again in the future. The government also strongly suspects that the disaster in Mina occurred due to panic factors that caused Hajj pilgrims to jostle each other. It means that the government of RI is carrying out its role and function as a strong state through the function of state activists. In this case, the Indonesian government is trying to gather initiatives to urge the government of KSA to immediately improve the management of the Hajj, especially in Mina, Saudi Arabia. The government also carries out the intermediate function of the country by handling external issues in Saudi Arabia as a whole. These external problems are directly related to 129 Hajj pilgrims from Indonesia who died in Saudi Arabia due to a disaster in Mina. The active steps of the government of RI prove that Indonesia is a strong country.

The role of the government of RI as a strong country, in carrying out the activist function in Saudi Arabia, also occurred during the leadership of President Soekarno. Moreover the first 
President of RI was known to have an international diplomatic approach out of the box or out of the ordinary. President Soekarno's first state visit to Saudi Arabia was an important event in the bilateral relation between RI and KSA. President Soekarno arrived at Jeddah Airport, Saudi Arabia, on July 24, 1955. In Jeddah, President was greetly welcome by the Head of State of KSA, King Saud bin Abdul Aziz al Saud. Also attending was Crown Prince of KSA, Prince Faisal, and other high officials. The arrival of the President Soekarno also aimed to perform the first Hajj. This visit became special because it was only three months after the implementation of the Conference of Asia and Africa (CAA) in April 1955 in Bandung, Indonesia. This visit was a resiprocal visit from the presence of Prince Faisal who led the delegation of KSA in the CAA event (Prasetyo, 2017, p. 263).

One of the traces of monumental diplomacy on a visit to Saudi Arabia was the idea of President Soekarno who asked King Saud to plant a tree of Mindi. Mindi tree planting aims to green the Arafah field in the city of Mecca, which is very barren and dry. The idea was then approved by King Saud. President Soekarno immediately sent thousands of Mindi tree seeds to Saudi Arabia. Until now, the plant named Latin Melia Azedarah L was widely known by the people of Saudi Arabia as the 'Soekarno Tree'. Thousands of Mindi trees can also grow as high as 3-4 meters and are able to green barren land covering an area of more than 1,000 hectares around Arafah desert. Now, the Mindi tree has been planted in the cities of Mecca and Medina. Mindi trees are chosen because they are able to survive without water and can live in the desert with extra-hot climates. Even the government of KSA also brings special land from Indonesia and Thailand so that the trees can thrive (Prasetyo, 2017, p. 264).

The idea of planting the mindi tree originated from the heat and sting that was felt by President Soekarno when performing the wukuf in the Arafah desert. According to Soekarno, the hot and dry air in the Arafah desert can at least be reduced by the coolness of the green plants like the mindi tree. In this pilgrimage, King Saud always accompanied President Soekarno. When carrying out wukuf at Arafah desert, President Soekarno was accompanied by King Saud. This event occurred on July 29, 1955. Even the two heads of state together climbed the Arafah hill. Both of them pray that Muslims around the world are united and can be released from foreign colonialism. President Soekarno also had the opportunity to take part in the ceremony to wash the Ka'bah building and enter to that holy building. He was also invited to attend the restoration ceremony of the Nabawi Mosque (Prophet's Mosque) in Madina. At that time, President Soekarno had the honor of casting as a sign of the commencement of the restoration of the Prophet's Mosque. As an engineer, President Soekarno was pleased with the opportunity. (Prasetyo, 2017, pp. 263-265).

Thus, the government of RI has pioneered a mutually beneficial interdependence relationship with the government of KSA. On the one hand, the government of KSA needs a Mindi tree species that can thrive in the desert with hot weather and minimal water. This is important because the government of KSA has an interest in providing the best services to Hajj pilgrims who come every year from all over the world, including to reduce the heat temperature in Arafah desert. On the other hand, the government of RI also saw a great opportunity to export the Mindi tree seeds to Saudi Arabia in the future. This is very strategic because it can prosper Indonesian society in the long run.

\section{CONCLUSION}

Indonesia is a strong country. It can be seen from the stance of the government of RI who support the Arabs nations, including Saudi Arabia, to against the Israeli occupation in Middle East area, especially in Palestine. The foreign policy of RI which is free and active also 
support Indonesia as a strong country. It can be seen from the refusal from the government of RI to send troops involved in Gulf War I. Although King Fahd asked President Soeharto to sent troops abroad to against the Iraqi attack on Kuwait, President Soeharto still could not approve the request. The reason is logic and rational, because the constitution of RI does not allow the president to send soldiers abroad involved in a war. However, the government of RI firmly rejects the government of Iraq's efforts to invade Kuwait. The reason is Quwait as a souvereign country whose independent and recognized de jure and de facto by the United Nations.

\section{ACKNOWLEDGEMENT}

This research based on grant scheme of PITTA (Publikasi International Terindeks untuk Tugas Akhir) or also known as Indexed International Publications for Final Projects toward Universitas Indonesia students. Thank you to Dr. Muhammad Luthfi as my advisor.

\section{REFERENCES}

[1]. Aditya Panji, "Tentang Jalan 204, Lokasi Musibah yang Tewaskan 310 Haji," CNN Indonesia, Thursday, September 24, 2015, https://www.cnnindonesia.com/ internasional/20150924172343-120-80792/tentang-jalan-204-lokasi-musibah-yangtewaskan-310-haji, downloaded on Tuesday, October 9, 2018, at 19:29 WIB.

[2]. Ambaranie Nadia Kemala Movanita, "Kapolri Titipkan WNI Yang Beribadah Haji Ke Kepolisian Arab Saudi,” Kompas.com, Thursday, Ausgust 31, 2017, https://nasional.kompas.com/read/2017/08/31/09470041/kapolri-titipkan-wni-yangberibadah -haji-ke-kepolisian-arab-saudi, downloaded on Friday, May 25, 2018, at 14:57 WIB.

[3]. Ambaranie Nadia Kemala Movanita, "Temui Kapolri, Kepolisian Arab Saudi Tindak Lanjuti MoU Pemberantasan Kejahatan Transnasional,” Kompas.com, Selasa, 18 April 2017. https://nasional.kompas.com/read/2017/04/18/13124831/ temui.kapolri.kepolisian.arab.saudi.tindak.lanjuti.mou.pemberantasan.kejahatan.transn asional, downloaded on Friday, May 25, 2018, at 13:44 WIB.

[4]. Ani Nursalikah, Editor, "Jokowi Sampaikan Duka Cita Mendalam untuk Korban Crane,” Republika.co.id, Saturday, September 12, 2015, http://nasional.republika. co.id/berita/nasional/umum/15/09/12/nujdb8366-jokowi-sampaikan-duka-citamendalam-untuk-korban-crane, downloaded on Sunday, July 1, 2018, at 08:26 WIB.

[5]. Bakri, Umar Suryadi, Dasar-Dasar Hubungan Internasional, 2017, Jakarta: Kencana.

[6]. Danu Damarjati, "Ini 11 MoU Antara Indonesia dan Arab Saudi," Detik.com, Wednesday, March 1, 2017, https://detik.com/news/berita/d-3435465/ini-11-mouantara-indonesia-dan-arab-saudi, downloaded on Saturday, May 26, 2018.

[7]. Departemen Perhubungan, Dephub.go.id, http://dephub.go.id/org/athubjeddah, downloaded on Wednesday, August 1, 2018, at 18:57 WIB.

[8]. Elin Yunita Kristanti, “7 Tragedi Mina dalam Kurun Waktu 1990-2015, Liputan6.com, September 24, 2015, https://m.liputan6.com/global/read/2325255 /7-tragedi-minadalam-kurun-waktu-1990-2015, downloaded on Friday, June 29, 2018, at 07:08 WIB.

[9]. Fukuyama, Francis, Memperkuat Negara: Tata Pemerintahan dan Tata Dunia Abad 21 (Translator: A. Zaim Rofiqi), 2005, Jakarta: PT. Gramedia Pustaka Utama, Freedom Institute, and Embassy of United Stated of America. Original title: State-Building: Governance and World Order in The 21-st Century. 
[10]. Hindra Liauw, "Begini Kronologi Jatuhnya 'Crane' di Masjidil Haram,” Kompas.com, September 2015, 12, https://internasional.kompas.com/ read/2015/09/12/02075551/Begini.Kronologi.Jatuhnya.Crane.di.Masjidil.Haram,

downloaded on Saturday, June 30, 2018, at 22:16 WIB.

[11]. http://atdikriyadh.org/, downloaded on Monday, May 7, 2018, at 20:59 WIB.

[12]. http://www.boxalamat.com/2016/10/alamat-kantor-kedutaan-besar-arab-saudi-untukindonesia.html, downloaded on Sunday, February 4, 2018, at 16:08 WIB.

[13]. https://www.kemlu.go.id/riyadh/id/tentang-perwakilan/pejabat-dan-staff.aspx, downloaded on Sunday, February 4, 2018, at 15.58 WIB.

[14]. "Korban Tewas Crane Roboh di Masjidil Haram 107 orang," Kompas.com, 12 September 2015, https://internasional.kompas.com/read/2015/09/12/07363541/ Korban.Tewas.Crane.Roboh.di.Masjidil.Haram.107.Orang, downloaded on Saturday, June 30, 2018, at 23:29 WIB.

[15]. Mei Amelia R, "Bertemu Kepala Polisi Saudi, Kapolri Titipkan WNI Yang Berhaji," Detik.com, Wednesday, August 30, 2017, https://detik.com/news/berita/ d3621128/bertemu-kepala-polisi-saudi-kapolri-titipkan-wni-yang-berhaji, downloaded on Friday, May 25, 2018, at 14:29 WIB.

[16]. Muhammad Ibrahim Hamdani, "Kunjungan Spektakuler Raja Salman: Diplomasi Bebas Aktif Indonesia," Dewan Masjid Indonesia (DMI), Thursday, March 2, 2017, http://dmi.or.id/kunjungan-spektakuler-raja-salman-diplomasi-bebas-aktif-indonesia, downloaded on Monday, February 5, 2018, at 13:52 WIB.

[17]. Muhammad Ibrahim Hamdani, "Raja Salman Instruksikan Penyelesaian Musibah Crane Secara Menyeluruh,” DMI.OR.ID, September 16, 2015, http://dmi.or.id/rajasalman-instruksikan-penyelesaian-musibah-crane-secara-menyeluruh/, downloaded on Tuesday, October 16, 2018, at 22:23 WIB.

[18]. Muhammad Ibrahim Hamdani, "Wapres Kalla: Musibah Masjidil Haram Mengandung Ujian dan Hikmah,” DMI.OR.ID, Sunday, September 13, 2015, http://dmi.or.id/wapres-kalla-musibah-masjidil-haram-mengandung-ujian-dan-hikmah/, downloaded on Sunday, July 1, 2018, at 08:35 WIB.

[19]. Muta'ali, Abdul, Membangun Negara Kuat, Kontribusi Islam Terhadap Pemikiran Politik Barat, 2013, Jakarta: Penerbit Universitas Indonesia (UI-Press).

[20]. Prasetyo, Sigit Aris, Dunia Dalam Genggaman Bung Karno, 2017, Bandung: Imania.

[21]. Ray Jordan, "Jokowi Berduka Atas Tragedi Mina, Minta Ada Perbaikan Pengelolaan Haji," Detik.com, Thursday, September 24, 2015, https://m.detik.com/news/berita/d3027671/jokowi-berduka-atas-tragedi-mina-minta-ada-perbaikan-pengelolaan-haji, downloaded on Thursday, October 10, 2018, at 03:34 WIB.

[22]. Resty Armenia, "Menteri Agama: 129 WNI Jadi Korban Tragedi Mina," CNN Indonesia, Friday, October 16, 2015, https://www.cnnindonesia.com/nasional/ 20151016212457-20-85430/menteri-agama-129-wni-jadi-korban-tragedi-mina, downloaded on Tuesday, October 9, 2018, at 19: 53 WIB.

[23]. Said, Amin, King Faisal: Raja Saudi Pelayan Umat, Penentang Imperialisme (Terj: Muhammad Ihsan), 2014, Jakarta: Pustaka Al-Kautsar. Originl Title: Faishal AlAzhim.

[24]. Team Dokumentasi Presiden RI, Jejak Langkah Pak Harto 1 Oktober 1965-27 Maret 1968, Series 1, 1991, Jakarta: PT. Citra Lamtoro Gug Persada.

[25]. Team Dokumentasi Presiden RI, Jejak Langkah Pak Harto 28 Maret 1968-23 Maret 1973, Series 2, 2003, Jakarta: PT. Citra Kharisma Bunda. 
[26]. Team Dokumentasi Presiden RI, Jejak Langkah Pak Harto 16 Maret 1983-11 Maret 1988, Series 5, 2003, Jakarta: PT. Citra Kharisma Bunda.

[27]. Team Dokumentasi Presiden RI, Jejak Langkah Pak Harto 21 Maret 1988 - 11 Maret 1993, Series 6, 2003, Jakarta: PT. Citra Kharisma Bunda.

[28]. "Tragedi Mina: Aparat Saudi Belokkan Arah Jemaah RI," Bbc.com, Sunday, September 27, 2015, https://www.bbc.com/indonesia/berita_indonesia/2015/09/ 150926_indonesia_mina_pembelokan_arah, downloaded on Thursday, October 10, 2018, at 16:32 WIB.

[29]. Video Arsip Nasional RI (ANRI), Kunjungan Kenegaraan Sri Baginda Raja Faisal Ibnu Abdul Aziz Al-Saud di Indonesia, on June 10-13, 1970, https://youtube/gu41voGv8Yo, downloaded on Saturday, April 1, 2018.

[30]. Yon Machmudi, "Saudi Arabia's Relation with Indonesia," in: Neil Partrick (Editor), Saudi Arabian Foreign Policy: Conflict and Cooperation, 2016, London \& New York: I.B. Tauris \& Co. Ltd., Part II, Chapter 16. 